\title{
INDEX OF CONTRIBUTORS OF ARTICLES AND NOTES
}

(The titles of articles are shown in capitals. A list of contributors to the Supplementary Publications published during 1962 follows this list)

AnEl, PAul, The Enforcement of Foreign Judgments against Partnerships (Blohu v. Dosser)

State Immunity (Decision of the Austrian Supreme Court of February 10, 1961)

Alexandrowice, Charles Hemry, The Sechetary-Gemeal of the UNited NaTions

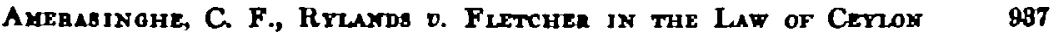

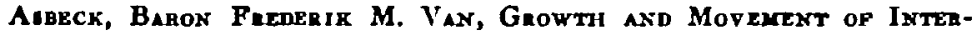
NATIOHAL LAW

Aupajcht, Hays, State Succeshoy under the Lat axd Practice op the Imteryational. Monetary Fuxd

Benomany, A. The Duty of the Degton to Protect the Cendizos

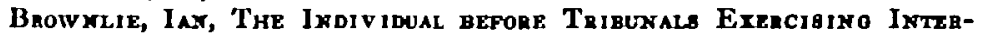
National JURigdiction

Bruzelius, Axdero, Ruthi Gingeura and, Paofeshoxal Leoni AbsibtAKCE IN SWEDEN

Buxgaum, David C., Preliminaky Taends in the Devejopment op the Leoal Ixotitutions of Comandist Chixa aNd the Nature of the Ceiminal Lay

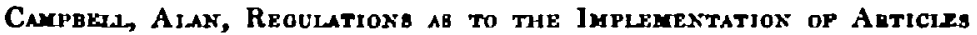
85 AND 86 OP THE Rome TiEaty

Colrx, E. J., The Arbitration Act, 1960, Section 4 (2) and the Geneva Protocol (The Traderman)

The Enforcement of Foreign Judgments against Partnershlps (Blohn v. Desser)

Damies, $W$. C. Ekow, The Impluence of Equity in Weat Afmicar Law

Daviea, S. G., Ghana : The Criminal Procedure Code, 1960

Nigeria-Some leccent Decisiona of the Coxatitution

Derrets, J. Duncay M., Indian Traditions and the Rule of Law Among Nations

Fictitious Transfers (Benami) and the Presumption of Advancement (Chattiar v. Chettiar)

Fitzagrald, P. J., State Succession and Personel Treatles (M/S Yangtze (London), Ltd. v. M/S Barlas Brothers (Karachl) \& Co.)

Givgeugo, Rumi and Axdens Brugelues, Profzssional Leoal AsastANCE IT SWEDES

Gimaburos, Gronor, The Sovjet Union, The Neutrals axd IxterNatioxal Lah ix Womid War 11

Goldie, L. F. E., Srecial. Réolmes axd Pae-edrptive hctivitixb ix I NTERNational. LaW

Grees, L. C., Political Offexces, War Ceimes axd Extanition

Gnoptcki, J. K., The Status of Incompetency (Re Langloy's Settlemont Trusts) 
Haydox, E. S., The Choice of Chixeae Custorany law in Howa Koxa

Hudsox, A. H., and G. D. Nokes, Irish Law in English Courtg-Some Further Points

Jakubowek1, J., The Setrumiext of Foneion Trade Draputes ix P'OLAKD

JAmes, Lesise, Bribery and Corruption in Commerce. The noed for the Harmonisation of Criminal Lave in European Countries

Jolinson, D. H. N., The Exolish Taditiox ix Ixteaxational Lap International Court of Justice. Judgments of May 26, 1961, and June 16, 1962. The Case Concerning the Tomple of Preak Vihear

Kalix-Faeuxb, O., Private International Law Committee, Sixth Report (Draft Convention on Monetary Law)

habiex, Dejmar, Tile Suprehe Covrt of the Uxited Statr.

Kumar, Malemona, R. Y. Pillai and, The Political axd Legal Statya OF KUWAit

laskix, Boza, Caxada's Bith of Rights: A Dilemsa for the Counto

Lasok, D., The Ejchmaxi Triat.

LeatzR, Asmoxy, Bizerta and the Unequal Treaty Theory

Lew is, P. S. C., with J. K. Geodecki and P. R. H. Wera, Nuluity Junisdiction: Thase Commentanies on the Ross Amith Case

McCisax, The Meanixo of Residexce

McCovvilez, D. A., Illegallty and the Consideration in Favorem Contractus (Etter v. Kortoz)

McPhrasox, B. H., The Passing of Property in English and South African Contracts of Sile

Manx, F. A., The Confibcatiox of Conporations, Corponatz Rjahto and Conponats Aasets axd the Conflict of Laws

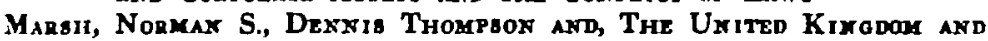
the Theaty of Rome: Sone Pazhmixany Oraervations The Late Mr. Hilary Stevens

Mausa Majxo, Lawyers and Legal Education in Burma

Mulszex, M. A., Eclipse of a Judiciary: The South African Position

Modinos, Polys, Efpects axp Repercussioxs or tile Eugopeas ConveNTIOK ox Huxax Riahts

Neghi, Zezv, The Preventiox of Nuisasces ix Ispaet.

Nokes, I. D., A. H. Hubsox and, I rish Law in English Courto-Some

Further Points
Oda, Shoegu, The Coxcrpt or the Controuova Zore

Pilial, R. V., and Mahexdan Kugur, The Political and Leoa. Status OP KuwatT

P'aAT, G. N., The Tenth Anniversary of the Institute of Air and Space Law-McGIII University

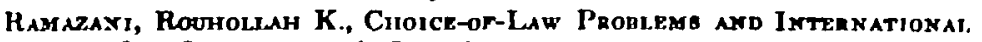
Onl Coxtracto : A Caes Study

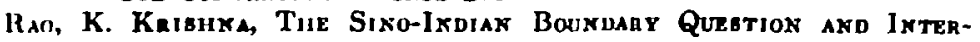
Natioxal. Lah

HeAm, Jaxes S., Ghana: The Criminal Code, 1960

Sarkan, Lotika, The Proper Lad of Cnime ix Internatioxai. Law 446

Sassoox, David M., Restrictive Practices In Israel

Scarmar, The Hox. Mr. Justice, Exolisil Law axd Foreion Adoption:

Schwerjx, Kurt, Law Ligaaries and Foreiox Law Colizctiox in THE U.S.A.

Sheridax, Lu A. Eqlal Opportuxity of Pyblic Employmest (NonDiscrimination in Public Services in India) 
Simarosp8, K. R., The "Rationale" of Diplonatic Immunity (Ghosh v. D'Rozario)

Siapave, Sartosh, Developments in the Legal Machinery of the United Nations

Spino, Enwix, Breach of Promise (Ouggonhoim v. Rosonbaum (2))

Thosipson, Dewris, and Nopman S. Massh, The United Krrodom axd the Treaty of Rome: Soye Prelimisant Ogseavatiors 78

The Bosch Case

Restrictive Practlces, Patents and Trade Marks in the Common Market

Valestirz, D. G., Amendment of the European Coal and Steel Communlty Treaty

The Nielsen Case. The European Commission on Human Rights

The Unesco Convention on the International Exchange of Publications

Weae, P. R. H., with J. K. Grodecki and P. S. C. Lewis, Noulitr Jebisdiction: Thake Commentaniea ox THE Ross Smith CABR

Forelgn Marriages Following Engligh Divorces (Broon (orse. Smilh) v. Brock)

Revocation of English Trust and Transfer of Funds to similar Forelgn Trust (Re Bealo's Marriago Sottlomont)

Weis, Pati, The Ukited Natioxe Conpertion on the Remction of Statelegokes, 1961

Wexoler, Wilhetm, Conflict of Lawa Propleas Relativa to Restitutios of Property in Gramany

Whock, I. D., A Civil Latreb Looks at the Cayor Lat

Yadiw, U., Reception and Rejection op Eyoliah Law in Igeate 


\section{INDEX OF CONTRIBUTORS TO SUPPLEMENTARY PUBLICATIONS IN 1962}

The following Supplementary Publicatlons are indexed below:

No. 8 (1962) The Encouragement and Protection of Investment in Developing Countries.

No. 4 (1962) Restrletive Practices, Patents, Trade Marks and Unfair Competition in the Common Market.

No. (1962) Labour Law in Europe: With Special Reference to the Common Market.

Supploment

Number Pago

Bern, Genyand, The Relationship between Community Law and the Lew of the Member States

Benewatzix, A., Terms of Employment Regulated by Legislation in Continental Europe (I)

$\begin{array}{ll}4 & 1 \\ 5 & 17 \\ 3 & 1 \\ 5 & 4\end{array}$

Chnx, Winfrax, The Relative Role of Governmental Assistance and Private Enterprise in Derelopment Overseas $\quad 3 \quad 59$

Cumaro, Sir Duxcas, The Middle East

3 82

De Hanx, C. J., The Protection of Trade Marks

Dadcren, Alpred, Comment on Survey of Current Approaches to the Problem, by Michael Brandox

Finm1so, G., Industrial Property and the Common Market

Flusidexi, Aluns, Terms of Employment Regulated by Legislation in the United KIngdom

Froscharaiza, F., The Draft Convention on Patents in the Common Market

Gradstoxe, Alay, Redundancy and Dismissal in Europe (II)

Grifriths, Sia Pencival, India, Pakistan and Burme

Hourx, R, Restrictive Practices Laws of France Unfair Competition and Passing Off in France and Germany

$+$

5

47

3

Joursox, D. H. N., Comment on Drafting of Conventions for the Protection of Investment, by ELI Lauteapicitr

Kaнк-Fazusd, Orro, Collective Agreements in the United Kingdom

Lautrapacht, El1, Drafting of Conventions for the Protection of Investment

Levexbach, Mariua G., Terms of Employment Regulated by Legislation in Continental Europe (II) 
$\mathrm{x}$ Index of Contributors to Supplementary Publications in 1166?

Supplament

Numiber Pago

Marsir, Noraras S., Unfalr Competition and English Laws. An Introductory Note with Particular Reference to Passing Off

Mussard, Rorand, The Regulation of Restrictive Business Practices and the Treaty of Rome

Oriemhauze, $H_{\text {, }}$ Labour Problems and Redevelopment in the European Conl and Steel Community

Peduxz, F. J., The Problems in East and West Africa $\quad$ y 63

Rama, Th., Collective Agreements in Germany

Works Councils in the Memuber States of the European Economic Conmunity

RAT, Gronaz W., Economic Developnent as the Hard Core of - Foreign Policy: An American Vlew

Richanns, R. B. J., The Role of the World Bank and its Affliates

Ripoche, Paur, The Achievements of the European Economic Community with regard to Investment in Developing Countries

Schurd, Foukx, Terms of Employment Regulated by Legdslation in Continental Europe (III)

Redundancy and Dlamissal in Europe (I)

Sterxdorm, E., Restrictive Practices Laws in Germany Unfalr Competition and Passing Off in Germany

Stephizxs, A. L. N., Shop Stewards and Works Councils in the United Kingdom

Redundancy and Dismlssal in the United Kingdom

Tea Korne, B. H., Restrictive Practices Laws of the Netheriands 440 


\section{INDEX OF CASES NOTED}

(Names of contributors are inserted in parenthoses)

Adegbenro 0 . Attorney-General of the Federation of Nigeria and Others : 1962, Nigeria F.S.C. (S. G. Davies) . . . . . . .

Akintola $v$. Governor of Western Nigeria and Adegbenro: 1962, Nigeria F.S.C. (S. G. Davies)

Attorney-General of the Government of Israel $c$. Adolf, the son of Karl Adolf Eichmann; 1962, Israel, Jerusalem District Court (D. Lasok)

Apstrian Supreme Court, Declsion of Feb. 10, 1961, 20b 248/60 (Paul Abel)

Blohn 0. Desser: 1961, Q.B.D. (E. J. Cohn) : . . . . .

Bosch and Van Rijn o. de Geus : 1962, Court of Justice of the European Communities (Dennis Thompson). . . . . . . 781

Breen (orse. Smith) o. Breen, 1961, P.D. (P. R. H. Webb) . . . . 201

Certain Expenses of the United Nations (Article 17, Paragraph 2 of the Charter) \& 1962, International Court of Justice (R. Y. Jennings) . 1169

Chettiar v. Chettlar i 1962, Prify Council (J. Duncan M. Derrett) . . 864

Eichmann Cese. Beo Attorney-General of the Government of Israel.

Etler o. Kertess : 1960, Canada, Ontario C. of A. (D. A. McConville) . 856

Expenses of the Unlted Nations. Seo Certain Expenses of the United Nations.

Ghosh v. D'Rozsrio : 1962, Court of Appeal (K. R. Simmonds) . . . 1204

Guggenheim v. Rosenbaum: 1961, South Africa (Erwin Spiro) . . . 260

Langley's Settlement Trusts, Ra : 1961, Court of Appeal (J. K. Grodecki) 678

M./S. Yangtre (London), Ltd. v. M./S. Barlas Brothers (Karachi) and Co. : 1961, Paldstan Supreme Court (P. J. Fitegerald) . . . 848

Nielsen Case, The: European Commission of Human RJghts (D. G. Valentine) . . . . . . . . . . . . .

Ross Smith v. Ross Smith: 1962, House of Lords (D. K. Grodectd, P. R. H. Webb and P. S. C. Lewis) . . . . . . . . . 651

Rylands 0 . Fletcher : 1868, House of Lords (C. F. Amerasinghe) . . 997

Seale's Marriage Settlement, Re \& 1961, Ch.D. (P. R. H. Webb) . . . 258

Temple of Preah Vlhear, Case Concerning: 1962, International Court of Justice (D. H. N. Johnson) . . . . . . . . . . 1188

Tradesman, The: 1961, P.D.A. (E. J. Cohn) . . . . . . . . 569

Williams v. MajekrodunmI : 1962, Nigeria F.S.C. (S. G. Davies) . . . 920 


\section{INDEX OF BOOK REVIEWS}

Allutt, Antony. Essays in African Law

Bamford, B. R. The Law of Partnerships and Voluntary Associations in South Africa

Bebr, Gerhard. Judicial Control of the European Communities 1288

Campbell, Alan, and Dennis Thompson. Common Market Law. Texts and Commenteries 902

Cassoni, Dott. Giuseppe. La Naxionalizzazione della Sacietá e il Diritto Internaxionale Private

Cheng, Bin. The Law of International Air Transport

Cheshire, G. C. Private International Law. Sixth Edition

Church, Edgar M. Business Associations under French Law 812

Citizen and the Adminlatration, The. A Report by Justice

Conférence de la Haye de Droit International Prive. Actes et Documenta

Current Law and Social Problems. Volume II de le Neuritme Session (4 Volumes) 1227

Deutsch, Dr. Erwin. Wettbewerbstatbestande mit Auslandsbezichung 898

Feinberg, Nathan. The Legality of a "State of War" after the Cessation of Hostilities

Gupte, S. V. Hindu Law of Marriage

Guyomar, Genevlève. Le Défaut des Parties a un Différent devant les Jurisdictions Internationales

Hellner, Jan. Kopratt [Sale of Goods]

Humes, Samuel, and Elleen M. Martin. The Structure of Local Government Throughout the World

Kahn, Phllippe. La Vente Commerclale internationale

Kamp, Herbert A. Zur Haftung ohne Verschulden des Kraftsfahrzeughajters (Gardien de l'autonobile) in franzobsischen Recht

Kasme, Dr. Badr. La Capacite de l'Organisation des Nations Unies de

Kelly, John Maurice. Fundarental Rights in the Irish Law and Con-

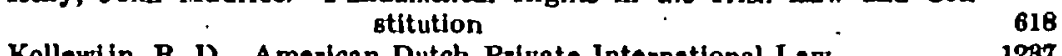

Kollewijn, R. D. American Dutch Private International Law

Kruse, Dr. Hans. Legal Aspects of the Peaceful Utilization of Atomic Energg

Lauterbach, Wolfgang. Vorschläge und Gutachten zur Reform des deutschen internationales Eherechts 1283

Law, Castor H.P. The Local Remedies Rule in International Law 296

Law in Eastern Europe, No. 5. The Law of Inheritance In Eastern Europe and the People's Republle of China

Lee, Luke T. Consular Law and Practice

Lacouras, Peter J. The Internstional Court of Justice. Materials on the International Court of Justice in Contentious Procedings 
Marek, Krystyna. Répertoire des Documents de la Cour de la Haye, Series 1, 1922-1946, Vol. 1, Drolt international et droit Interne

Mlyezald, Kojuro (Editor). A Comparison of Laws Relating to Marriage and Dirorce. Part II.

Nadelman, Kurt H. (Editor). XXth Century Comparative and Conflicts Lav

Petitjean, Henri. Fondements et méchanisme de la transmission succesmorale en droit françals et en drolt anglais; étude de droit compare et de drolt international prive

Phillp, Allan. Studier I den Internationale Selskabrets Teori

Plodelen, Stanlslaw. Lex Rhodla de Iactu

Profesalonal Secrecy and the Journalist. International Press Institute

Pryce, Roy. The Political Future of the European Community

Scandinavian Legal Blbliography

Scandinarlan Studies in Law, 1961

Schlochauer, Dr. Hans Jurgen. Wörterbuch des Vülkerrechts. Second edition

Schmitthoff, Clive M. The Export Trade

Sharp, Walter R. Field Administration in the United Nations Syatem

Sheridan, Prof. L. A. (Editor). Malaya and Singapore: The Borneo Territories

Smith, T. B. British Justice: The Scottigh Contribution

Sconsvala, J. K. The Supreme Court on Criminal Law, 1960 to 1860

Stone, Jullus. The International Court and World Crisis

Stromholm, Stig. Torts In the Conflicts of Laws 802

Sundberg, Jacob W. F. Air Charter, A Study in Legal Development 1224

Syataum, J. J. G. Some Newly Established Asian States and the Development of International Law

Thompson, Dennis. Ses Campbell, Alan.

van der Sprenkel. Legal Institutions in Manchu China. A Soclological Anialysis

van Ommeslaghe, Pierre. La Régime des Sociétés par Actions et leur Administration en Drolt Comparé

Vitta, Edoardo. L'Internasione Europea. Studio Sulle Analogie ed Influenze di Diritte Publico Interne Negli Institute di Integrasione Europea

von Overbeck, Alfred. L'Unification des Rigles de Conflits de Lois en

Wade, H. W. R. Administrative Law Matiere de Forme de Testaments 1229

Weissberg, Guenter. The International Status of the United Nations Wetter, J. Gullis. Diplomatic Assistance to Private Investment. A Study of the Theory and Practice of the United States during the Twentleth Century

White, Gillian. Nationalisation of Foreign Property

Woetrel, Robert K. The Nuremberg Trials In International Law

Yankav, Alekaander. Reservite $\nabla$ Deklaracilte $2 a$ Priemane Zadalahitelnata Yurisdikcia ne Mechdunarodnlya Sad I Tyakhnoto Vliyanie Varkhu Kompetentnostta na Snda 


\section{INDEX OF SHORTER BOOK NOTICES AND BOOKS RECEIVED}

Acte Juridice 1960

328

917

634

328

Annual Survey of South African Law, 1960

Aufricht, Hans. Central Banking Legislation. A Collection of Central Bank, Monetary and Banking Laws

Azar, Antolne. Genese de la Constitution du 4 Oetobre, 1968. Solution Gaulliste a la Crise du Pouvoir

Basu, Durga Das. Commentary on the Constitution of India. Fourth Edition

Shorter Constitution of India. Third Edition

Introduction to the Constitution of India. Second Edition

Beauté, Jean. Le Drolt de Petition dans les Territolres Sous Tutelle

Bedjaoul, Mohammed. Law and the Algerian Revolution

Bentíoglio, Ludovico Matteo. Diritto Internazlonale Pubblico

Bittker, Boris 1., and Lawrence F. Ebb. Taxation of Foreign Income. Cases and Materials

Blagojevis, Prof. Borislav T. The Legal Status of Agricultural Land

Bouin, Leon. The Changes Effected in the Soviet Criminal Law by the Leglslation of December, 1858

Cappellett, Mauro. La Jurisdiccion Constitucional de la Libertad. Con Referencia a los Ordenamientos Aleman, Suize y Austriaco

Clericett, Dario. L'Afialre Ambatlelos devant la Commission Arbitrale

Cotteret, Jean-Marie. Le Pouruir Legislatif en France

Devlin, Patrick. Samples of Lawmaking

Dicey, A. V. Lectures on the Relation between Law and Public Opinion in England during the Nineteenth Century

Documents on the Expulsion of the Germans from Central Europe. Vol. II/III

Dokumente Zur Deutschlandpolitik III Reihe/Band I

Dowrick, F. E. Justice according to the English Common Lawyers

Eek, Hilding. Internationell Privatratt Metod och Material

Fait et le Droit, Le. Etudes de Logique Juridique

Gamillscheg, Franz Die Deutsche Rechtsprechung auf dem Gebeite des internationalen Privatrechts in den Jahren 1986

'Garcia-Mora, Manuel R. Internationa] Responsibility for Hostile Acts of Private Persons against Foreign States

Germann, Oscar Adolf. Prajudizien als Rechtsquelle. Eine Studie zu der Methoden des Rechtsfindung

Hanson, A. H., and H. V. Wiseman, Parliament at Work

Jahrbuch des Offentlichen Rechts der Gegenwart. Neue Folge/Band $1001 \%$

Jenks, C. Wufred. The Proper Law of International Organisations 1261

Jennings, Sir Ivor. The British Constitution. Fourth edition 828

Karelle, Jacques, and Fritz de Kernmetu. Le Benelux Commenté. Textes Officiels

Kelly, J. M. Fundamental Rights in the Irish Law and Constitution 
Kircheimer, Otto. Political Justice. The Use of Legal Procedure for Political Ends

Koch, F. E., and V. Uckmar. The Convention between the United Kingdom of Great Britain and Northern Ireland and the Italian Republic for the A roldance of Double Taxation and the Prevention of Fiscal Evasion with respect to Taxes on Income

Larson, Arthur. When Nations Disagree. A Handbook on Pcace through Law

Laun, Rudolf. Allgemeine Staatslehre in Grundriss eln Studienbehelf 1264

Law in Eastern Europe, No. 6. Studies in Polish Law.

Legal Aspects of Neutrality. Proceedings of the Third Commission, VIIth Congress of the International Associntion of Democratic Lawyers, Sofia, 10-14 October 1960

Lever, Jeremy. The Law of Restrictive Trade Agreements

Lewis, A. K., and J. A. Kemp. Registration of Commercial and Licence Agreements in the Common Market 1262

McWhinny, Eduard. Constitutionalism in Germany and the Federal Constitutional Court Judicial Review in the English-Speaking World. Second edition

Makarov, A. N. Allgemelne Lehren des Stantsangehorigkeits rechts. Second edition

Maung Maung. A Trial in Burma. The Assassination of Aug San

Meder. Dr. Walter. Grundlagen des Zlvilrechts und des Zivilprozessrechts du U.D.S.S.R.

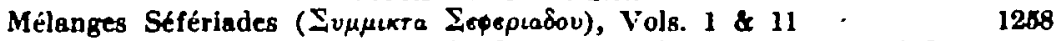

Minattur, Joseph. Freedom of the Press in India. Constitutional Provisions and their Application

Miyazaki, Kojiro (Editor). A Comparison of Laws Relating to Marriage and Divorce. Vol. III, America (2) and Europe (2)

Moral-Loper, Pedro. Princlples of Land Consolidation Legislation 1263

Nordisk Kriminalistisk Arsbok 1960. De Nordtska Kriminalist foreningarnas A rsbok

Nordisk Rad. 9th Session, 1961

Ollé-Laprune, Jacques. La Stabilité des Ministres sous la Troisième République 1879-1940

Outer Space, Third Colloquium on the Law of. XIth laternational

Astronautical Congress, Stockholm 1960
Packner, Herbert L. Ex-Communist Witnesses. Four Studies in Fact Finding

Perrett, Robert-Louis. De la Paute et du Devoir en droit International.

Fondernent de responsabilité

P'inder, John. Britain and the Common Market

Pollock, Sir Frederick. Jurisprudence and Legal Essay'B

Powell, Raphael. The Law of Agency. Second edition

Présentés au sixlème Congres International de Droit Comparé

Pylee, M. V. India's Constitutlon

Richardson, H. G., and G. O. Sayles. Parliaments and Great Councils in Medieval England

Rohreke, Huns Georg. The Formal and Muterial Concept of Flag Equality

Rytkolá, Olavi. Finnisches Genoeindeverualtungsrecht, Ius Finlandiae, No. 4 
Sassoon, David 31. Road Aceldent Insurance. (A critical review of the existing law and proposals for its amendment) 1263

Schlochauer, Hang-Jurgen. Die Extraterritoriale Wirkung von Hoheitsakten. Nach den Offentlichen recht des Bundesrepublik Deutschland und nach Internationalem Recht

Schwarzenberger, Georg. The Frontiers of International Law

Schweizerisches Jahrbuch für internationales Recht. Annuaire Sulsse de

Droit International

Seeger, Roland. Le Status personnel des étrangers ennemis et la Convention de Genève du sont 1949 relative à le protection des civils

Sharma, Indra D. Modern Constitutions at work

Sinha, A. N. Law of Citizenship and Aliens in India 1268

Slesser, The Rt. Hon. Sir Henry. The Art of Judgment and other Studies 917

Somall Peninsula : A New Light on Imperial Motives 694

Sortais, Jean-Pierre. Le Titre et l'Emolument 1268

Sotiropoulos, Dr. Panayotis K. Die Beschrankung Der Reederhaftung.

Elne rechtshistorische und rechtsvergleichende Studie 1262

Steindora, Ernst. Problemes des Prix Imposés dans le Marché Commun 1262

Stone, Julius. Quest for Survival. The Role of Law and Foreign Policy 825

Stumpf, Friedrich. Motlv und Schuld. Eine psychiatrische studie uber den Handlungraufbau bel kriminellem Verhalten

Thorneycroft, Elizabeth. Personal Responsibility and the Law of Nations Topolskt and Cowper. Topolsk's Legal London

Troller, Dr. Kamen. Das Internationale Privatrecht des Unlauteren Wettbewerbs in vergleichender Darstellung der Rechte Deutschlands, Englands, Frankreichs, Italiens, Der Schweiz, and der U.S.A.

Turner, Amedée E. The Law of Trade Secrets

Tussman, Joseph. The Supreme Court on Church and State

Waelbrook, Michael. Le transport de la propriété dans la vente d'objets

Where to Look for Your Law mobiliers corporels en droit comparé 1264

Wilson, Roy, and Brian Galpln. Maxwell on the Interpretation of

Yearbook of Legal Studies, 1960

Yearbook of World Affairs, 1961

Yiannopoulos, Athanassios N. Negligence Clauses and the Brussels Convention of 1824. A Comparative Study 


\section{SUBJECT INDEX OF ARTICLES, NOTES AND DECISIONS}

Including Articles from the following Supplementary Publications :

No. 8 (1962) The Encouragement and Protection of Investment in Developing Countries.

No. 4 (1962) Restrictive Practices, Patents, Trade Marks and Unfair Competition in the Common Market.

No. 6 (1962) Labour Law in Europe with Special Reference to the Common Market.

References to these supplements are to the Number of the Supplement and the page. The titles of these supplements and of articles in the I.C.L.Q. are shown in capitals.

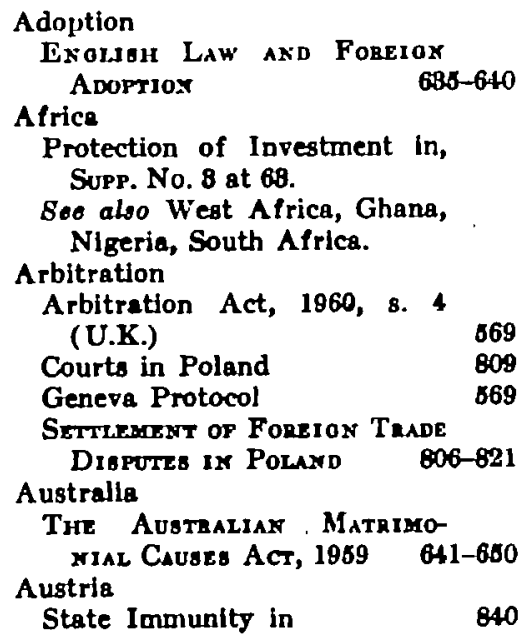

Adoption

Exoldoh LaW aNd Foreiox Adoptiox

$685-640$

Africe

Protection of Investment in, Supp. No. 8 at 68.

See also West Africa, Ghana, Nigeria, South Africa.

Arbitration

Arbitration Act, 1960, 8. 4 (U.K.)

Courts in Poland

Genera Protocol

SetTrement of Foreian Trade Dinpotes ix Polaxd

806-821

\section{Australia}

The Austenlias, Matrimowial Causes ACT, 1959 641-650

Austria

State Immunity in

840

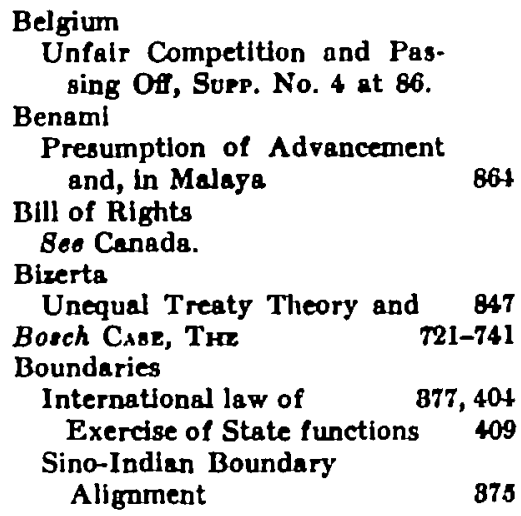

Boundaries-cont.

Sino-Indian Boundary-cont.

Historical Origin

SINO-INDIAN BoUTRART Question AND INTERxaTIONAL LaA $875-415$ Treaties Concerning 884

Breach of Promise $\quad 260$

Bribery in Comuerce

Laws of

880

Burma.

809 Lawyers and Legal Education in 286

Protection of Inrestment in, Supp. No. 8 at 78.

Canada

Bill of Rights, Text

Cayada's Bill, of Riahts : A Dilemima por the CoOrts 819-580

Canon Law

A Civil Lafyer Looks at the

Ceylon

Caron Law 89-107

Roman-Dutch law in

966

Rylande v. Flotcher iN THE

LAw of CeYzow · 937-975

China

Courts in 8

Criminal Law and the Court 16

Customary Law Choicr of Chinese Customar $\mathrm{Y}$ Law ix Howo Koxo

291-250

Developyext CP THE Lean INSTITUTIONS or CoMmumist Chisa axd the Nature of the Catmixal Law $1-30$ 
Chins-cont.

Legal Theory

Seo also Boundaries.

Civll Law

a Civil hapter Looks at the Caros Lat 89-107

Common Market

See European Economic Community.

Company, .ee Corporation.

Confiscation of Property

Compiacation of Conponthoxs, Conposate A Baete a d THE CONPLict of Laws 471-602

DUty of the Debtor to Protect the Caeditor

742-781

Sos aloo Restitution.

Conflict of Laws, ses Criminal Law Confiscation, Oil Contracts, Status, etc.

Contiguous Zone, The

Concept of the Contiouous ZoNe

181-153

International Law Commission and

Contract

in favorem contractus principle

Israeli liw of

Proper law of Marriage Contract

Sale of, Passing of Property

Uberrimae fidel, ses Debtor.

Corporations

Conflscation of assets of foreign Company, sos Corfigcation of Cobpogations, Conpogate Asgets axd tite Conplict op Laws

471-602

Criminal Jurisdiction

Proper Law of Calme ix Ixternatioxal Law

$446-470$

Territorial Princlple

447

Nationality

"Protective Principle"

466

462

Criminal Law

Proper Laf of Caime in IrTERational LatW

See also China, Ghana.

Criminal Procedure

See China, Ghana.

\section{Debtor}

Contracts Uberrimae fidei

Dutr of the Debtox to ProTECT THE Carditor
Developing Countries

Seo Investment in Developing Countries.

Diplomatic Immunity

Dirorce

The Auetratiax Mateimomial Caused ACt, $1959 \quad 641-660$

Domicle

See Nullity, Residence.

Eichmane Trial, The 355-874

Defence

859

Judgrnent

$\mathbf{8 6 7}$

Prosecution Case $\quad 858$

English Courts

Irish law in

English Law

Contracts of Sale

Exolisit Law and Forelor ADoptioxs

Isaazi, Reception aNd REJecTION OP Exoligh Law ix 89-72

Unfair Competition, Supp. No. 4 at 67.

Seo aloo United Kingdom.

Equity

I FFLUEACE OF Equity iY West A Farcas Lat 81- 68

Doctrines of Equity

86

Natural Justice 84

European Coal and Steel Community

Labour Problems, Supp. No. 5 at 8.

Treaty, Amendment of

European Commission of Human Rights

De Becker Case

Lawless Case

714,1104

Lebean Case

1108

Nielsen Case

886

Sos also European Convention of Human Hights.

European Convention of Human Rights

Effects and Repercussions op the Eunopean Convertion on Huras Riolts:

Individual right of Petition 1102

European Communities Court of Justice

English Courts and

Statute of the Court 789

Jiuropean Economic Community

Bosch Ca8e, The 721-741, 1027

European Social Fund, Sopp. No. 5 at 75 .

Industrial Property in, Surp. No. 4 at 47. 
European Economic Community -cont.

Investnent in Developing Countries, Supp. No. 8 at 46.

Labour Law in Europe: With Special Referessce to the Conyox Market, Supr. No. b.

Natlonality

Patents, Draft Convention, Sopp. No. 4 at 60.

Regulatrors as to THE ImpleHentatiox of AETICLEs 86 ANd 86 of the Rohe TeEaty

Regulation 17

Regulation 27

Restrictive Practices, 1027-1088

1087

1046

721-741, $1027-1068$

Reoteictife Peactices, Pateyte, Trade Marke ard Unpais Competition ix THE Cosoroy Manket, SupP. No. 4.

Regulation of Restrictive Practices, SUPP. No. 4 at 16.

Trade Marks, Supp No. 4 at 60 . Treaty of Rome

Article 86 (2)

Articles 85 and 86, sed Regulations.

UNITED Kixadoy AND THE TneAtr of Rayr 78-88

Workers, Movement of

Ser also European Communities Court of Justice.

Extradition

Political Comerces, Waz Ceintza aud Extraditioy 829-864

\footnotetext{
Foreign Judgment

Enforcement against Partnership

Poreign Merriage

English Divorce, following

Foreign Trust

Transfer of funds to

France

Labour Law

Collective Agreements, Supp. No. 6 at 4.

Restrictive Practice Law, Supr. No. 4 at 26.

Unfalr Competition and Passing Off, Supp. No. 4 at 86.
}

German Debts, Agreement on, 1952-58
Germany

Labour Law

Collective Agreements, Supp.

No. 8 at $\theta$.

Restrictive Practices, Supp. No. 4 at 28.

Unfalr Competition and Passing Off, Supp. No. 4 at 81.

Ses also Conflict of Laws, Restitution.

Ghans

Criminal Code, 1960

272

Criminal Procedure Code, 1960

Hong Kong

The Choice of Chinese Costomary law in Homo Koro

281-250

Human Rights

Seo Canada, European Convention, European Commiasion.

India

Constitution

Equal Oppontuxitt of PubLic EMplo ThexT $788-800$

Investments in, Protection of, SuPp. No. 8 at 78.

Law, 000 Benami.

Sequestration of Property

Traditions of, and the Rule of Law among Nations

Sea also Bounderles.

Individual

Criminal responsibulity in International law

Pracedural capacity

Subject of International Law, sos International Courts and Tribunals.

See also European Convention of Human Rights.

Industrial Property

Common Market and, Supr. No. 4 at 47.

Institute of Air and Space Law, McGill University 290,696

International Court of Justice

Expenses of the United Nations case, 1962

Individuals before, soe International Courts and Tribunals.

Judgments of the Administrative Tribunal of the I.L.O.

Parties before

Temple of Preah Vihear Case, 
International Courts and Tribunals

Tie Individual Berone Taibunals Exercisixo IxteaNational JUaigdictiox 700-720

International Labour Office $\quad 1059$

Judgments of the Administrative Tribunal of the I.L.O.

International Law

Codification of

Emolish Tradition is ImTrRYATIOHAL LAW

Growty and Movexome of INTEENATIONAL IaW 1054-1072

Indian Traditions and the Rule of Law Among Nations

Sprcial Reotuces and ParEhptive Activitieg is IxTERNATIONAL LAW 670-700

International Law Commission Codification of International Law

Enlargemient of

Special Missions

Seo aleo Contiguous Zone.

International Monetary Fund

STATE Succenalos UNDER THE Law ayt Pactice of the International Moketaky Fund

$104-170,695$

International Unions

Internetional Waterways

Investment in Developing Countries

Conventions to Protect, Supp. No. 8 at 18.

E.E.C. and, Surp. No. 8 at 45.

East and West Africa, Supp. No. 8 at 68 .

Encounnaement and ProtrcTJON OP INVERTMENT IN Developing Countries, SupP. No. 3.

Government Resistance and Private Enterprise, Supp. No. 3 at 69.

India, Pakistan and Burma, SupP. No. 8 at 78.

Middle East, Supp. No. 8 at 82.

U.S. Forelgn Policy and, Supp. No. 8 at 80.

World Bank and, Supp. No. 8 at $\mathbf{3 6}$.

Iran, ses Oil Contracts.

Irag

Kuwait, claim to

Irish law in English Courts 250

Israel

Contract law
Israel-cont.

English law

Recrption and Rejection OF ENOLIBH LAF IX IaBaEL 69-72

Nuisance

Paeveatiox of Nuisances

IN IorazL 820-895

Restrictive Trade Practices in 279

Tort, lew of

Japanese Occupation

Confiscation of Property

765

Judgments

Soo Foreign Judgment.

Jurisdiction

Sec Criminal Jurisdiction.

Kuwalt

Iraq's Claim

Political ate Leoal Status

op Kuwarx

$108-180$

Labour Law

Collective Agreements

United Kingdom, Supp. No. 6 at 1.

France, Supp. No. $B$ at 4.

Germany, SupP. No. $\delta$ at 9.

European Coal and Steel Community, Supr. No. 6 at 85.

European Social Fund, Surp. No. 5 at 76.

Ladour Law in Europe: With Special Refenerce to THE Coysron Marget, Supp No. 6.

Legislation regulations, terms of employment .

United Kingdom, Surp. No. 5 at 18.

Continental Europe, Supp. No. 5 at 17,23 and 82 .

Redundancy and Dlsmissal

Europe, Supp. No. 6 at 62 and 68 .

United Kingdom, Supp. No. 5 at 70.

Shop stewnrds

United Kingdom, Supp. No. 5 at 86.

E.E.C., Surp. No. 8 at 89.

Works Councils

United Kingdom, Supp. No. 5 at 86

L.E.C., Supp. No. 8 at 89.

Law Libraries

American Law Libraries

Foreign Law Collections in the U.S.A. 
Innd Libraries-cont.

Law Lidharyes axd Foreiox LaW CollectioNs IN THE U.S.A.

$687-567$

Lawless Case, The

Legal Aid

Sweden

Legal Education

Lawyers and Legal Education in Burms

Sweden

Legal Profession, the

Notaries in Sweden

Professional Legal AssisTAKCE IN SwEDEX

Professional Legal Assistance in Sweden

State Representatives in Sweden

1017

Librarles

Seo Law Libraries.

Malaya, Law of

Benami, law of

Marriage

The Aubtraliax Mateimoyial Caugzs ACT, 1959 641-680

See also Foreign Marriage.

Middle East

Protection of Investments in, Surp. No. 8 at 82.

Monetary Law

Draft Convention, P.I.L. Comnittee

Nationality

See Crimina Jurisdiction, European Economic Community.

Natural Justice

Soe West Afrlca.

Netherlands

Restrictive Practices Laws, Supp. No. 4 at 40.

Neutrality

Commerclal and Economic

Moral or Ideological Neutrality

Soriet Uxiox, The Neutales AND INTERSatjosal Laf ix WonLD War II

Territorial Neutrality

Unneutral Services

215

Nielsen Case, The

Nigeria

Nroenia-Sose Recest Decishoxs of the Coxatitution
Nigeria-cont.

Western Nigeria, Parliamentary Disturbances

919-986

Nulsance

The Prevention of Nuigaxces in I BrazL 822-835

Boe also Rylande v. Flotehor.

Nullity

Nutuite Junisdiction ; TheEe COMMENTaRIEs on THE Ross Smith CABE

651-669

Ofl Contracts

Ciloice-of-Law Probuemi axd IXTERMATIONAL OIL ConTRACTs : A Cabe StUdy 608-678

International law applied to 610

Iranian law applied to

610

Pakistan

Protection of Investment in, Supp. No. 3 at 78.

Partnership

Soe Forelgn Judgrments.

Passing Off

Belgtum, Supp. No. 4 at 86.

English Law, Surp. No. 4 at 67.

France, Supp No. 4 at 86.

Germeny, Surp. No. 4 at 81

Patents

Reathictive Practices, Patents, Trade Marke avd UNPair COMPETITIOY IY THE Common Mabut, Supp. No. 4.

Polend

Tife Setrlemert of Foneioy Trade Disputes is Polayn

Arbitration Courts in 806-621

Political Offences

Sos Extradition.

Pre-emptive Activities

Special Reatmes and Preemptive Activities ix INTERNATIONAL LAW

Private International Law, ... Conflict of Laws, Private International I aw Committee.

Private International Law Committee

Draft Convention on Monetary Law

Public Employment

Baval Oppostunity of Pudic Emploranest (Non-Discrimination in public services in India) 
Residexce, the Measino of 1168-1168 liestitution

Conflict of Lafis Phoplems Relatisa to Restitution of Peopeatr in Germant 1181-1162 in natura 1184

Restitutfon Courts in Germany

Restrictive Trade Practices $1181-1159$

European Economic Community

Reataictive Practices, Patento, Trade Markg axd Untain Competition ix the Consion Market, Supp. No. 4.

France, Supp. No. 4 at 26.

Germany, SuPP. No. 4 at 28.

Israel, in

Netherlands, Supp. No. 4 at 40.

Sec also, Passing Off, Unfair Competition.

Roman-Dutch Law of culpa

Rome Treaty

Soe European Economic Community.

Rylands $\nabla$. Flotohor in tHE LAW of Cerlor

987-975

Sale of Goods Passing of Property 878

Sea, Lat of

Colliations

Ses also Contiguous Zone.

Secretary General, see United Nations.

South Africa

Contracts of Sale 878

Judiciary of

Rylands v. Flotcher in

Special Missions

Speciat Regimes amd Pae-rucpTIVE ACTIVITIEs iN INTERNaTIONAL LAW

$670-700$

State Immunity

Austrian decision

Statelessness

Uxited Nations Convention ON THE REDUCTION or Statelegsxe8a, 1961 107a-1096 History of Convention 1078 Conference 1078 Text of Convention 1090

State Succession

Africa

Merger of States

1210

Pakistan

Partition of States

Personal Treaties and
State Succession-cont.

Release of Territory

STatr. Succesg yoy UNDeg the Law and Peactice op the Jaternational Moxetals: Fuxd

15t-170

Tanganyika $\quad 1210$

Transfer of Territory 161

Status

foreign, in Private International Law $\quad 578$

incompetency $\quad \mathbf{5 7 8}$

Sweden

Propegaloral Leani AsaisTAXCE is SweoEN 997-1026

See also Legal Aid, Legal Profession.

Tort

Israeli law of

Trade Marks

Comunon Market, in, Supr. No. 4 at 60 .

Regtaictive Paacticeb, Paterts, Trade Marks and Untair Competitjoa in tile Cosimion Mareet, Supp. No. 4.

Trenty

Unequal, Blzerta and

Treaty of Rome

Sac European Economic Community.

Trusts

Revocation of

Transfer of funds to. Foreign Trust

Uxeaco

Convention on the International Exchange of Publications

U.S.S.R.

Soo Neutrality.

840 Unequal Tresty Theory

Unfair Competition

Belgium, Supp. No. 4 at 86

European Economic Community

Rebifictive Practices, Patexts, Trade Maeks axd Uyrala Competitiox is the Comoror Manket, Supp. No. 4.

English law of, Supp. No. 4 at 67.

France, Supp. No. 4 at 86

Germany; Supr. No. at 81 . 


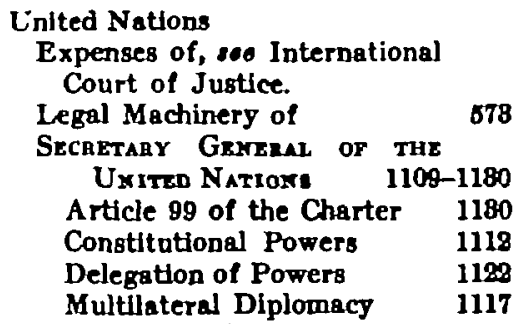

Court of Justice of the European Communities and EngJish Court

European Economic Community

UXITED KixadoH AFD THE Treaty of Roure

Legdslation and

Municipal law and

Workers, movement of

Labour Law

Collective Agreemento, Sopp. No. 6 at 1.

Leglslation regulating employment, Surp. No. o at 18.
United Kingdom-eont.

Labour Law-cont.

Redundancy and Dismissal, Supp. No. 6 at 70.

Shop Stewards and Works Counclls, Surp. No. 8 at 86.

United States

Foreign Policy, soo Investment

in Developing Countrles.

SUPhaxe Covet of the Uxited States $976-996$

S6o also Law Idbrarles.

War Crimes

Political Ophexces, War Caimes and Extraditiox 829-854

Boo also Eichmann.

War, Law of, sen Neutrality.

West Africa

Natural Justice, and Customary Law

The Ixplukerce of Eedity Ix West Arnicas Law 81-68

World Bank

Protection of Investments and, Supr. No. 8 at 86. 